\title{
EFFECT OF HIGH TEMPERATURE ON THE MECHANICAL STRENGTH OF BONE POWDER CONCRETE MORTAR
}

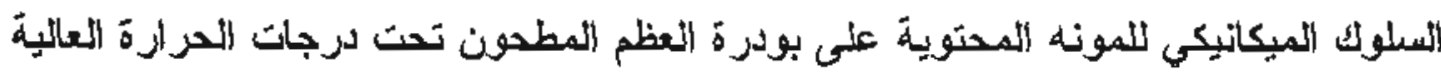 \\ M.H. Seleem', M. M. Balaha', M. H. A. kotb ${ }^{2}$, and H. Abd et-rahman \\ 'Assistam Prof.. Faculty of Engineering, Zagazig Universily. Zagazig, Egypt. \\ ${ }^{2}$ Prof., Faculty of Eng. Al-Azhar University, Nasr City, Egypt \\ E-Mail Balaha_336@yahoo.com
}

المعلخص المعزيى

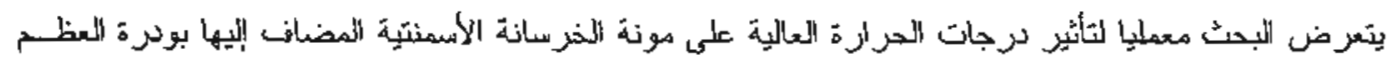

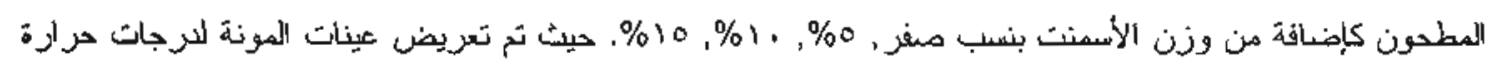

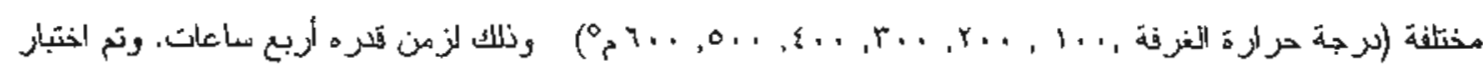

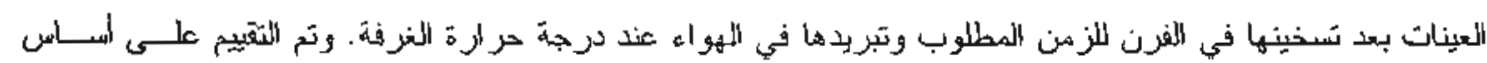

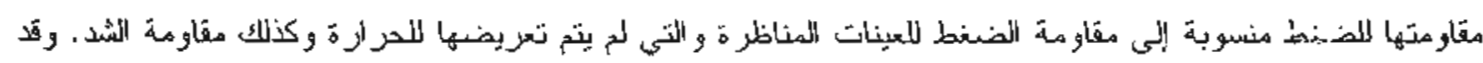

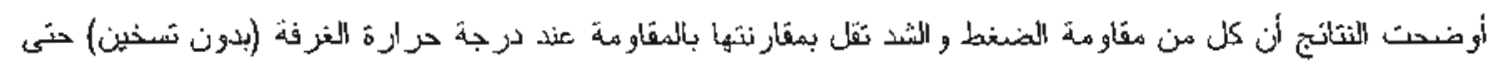

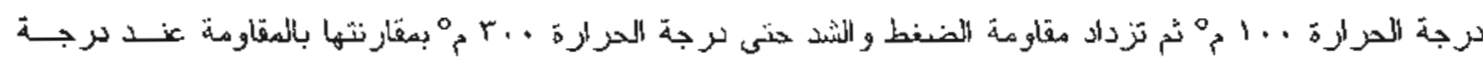

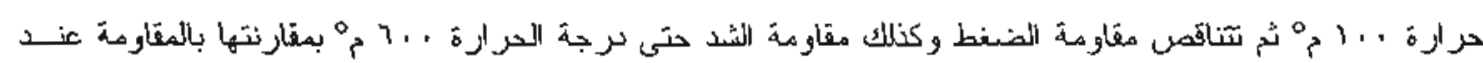

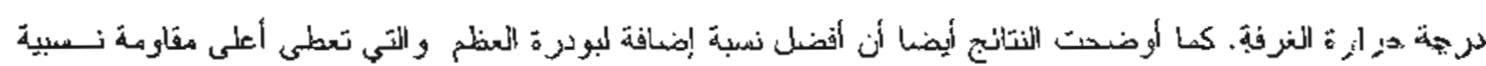

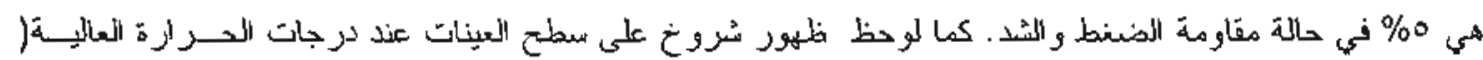

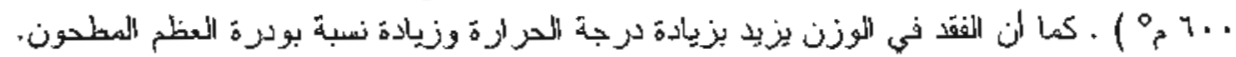

\section{ABSTRACT}

When building malerials are subjected to lire and exposed to cooling. some changes may occur in their chantacteristics; such as phase transformation, wcight loss, aggregatecement bond, etc., which directly affects on its chemical stability and mechanical properties. The effect of high temperature on the compressive and tensile strengths of concrete mortar premixed with bone powder (B.P.) as an addition as weight percent of cement was experimentally investigaled. The percentages additions of bone powder were $0 \% 5 \%, 10 \%$ and $15 \%$. All mortar samples were prepared and cured in tap water for 28 days, then kept in laboratory atmosphere until the beginning of the test. The specimens were subjected to different target temperatures of $100,200,300,400,500$ and $600^{\circ} \mathrm{C}$. Alter reacling to the desired target temperature, the specimens were hold at that temperature for 4 hours. Alter heating the specimens were altowed to coot al room temperature unlil the date of the test. The results showed that all mortar specimens exposed to high temperalure suffered a significant decrease in both compressive and tensile strengths. Addition of bone powder for concrete mortar by $5 \%$ recorded the highest relative compressive and tensile strength compared to other addition ratios. The mass loss increased with increasing temperature up to $600^{\circ} \mathrm{C}$ and B.P.\%. In addition, at temperature of $600^{\circ} \mathrm{C}$, cracks appeared on the surface of specimens.

KEY WORDS: Bone powder, Mortar, High Temperature, Compressive strength, Tensile sirength.

Accepted June 30, 2008 


\section{79 M.H. Seleem, M. M. Balaha, M. H. A. Kolb and H. Abd el-Rahman}

\section{INTRODUCTION}

Waste utilization is an attractive atternative to disposal in that disposal cost and potential pollution problems are reduced or even eliminated along with the achievement of resource conservation. Nevertheless, the utilization strategy must be coupled with environmental and energy considerations to use available materials most efficiently. Bone meal is a mixture of crushed and coarsely ground bones that is used as an organic fertilizer for plants and in animal feed. As a fertilizer, bone meal is primarily used as a source of phosphorus. Bone meal is used as a supplement for calcium and phosphorus. It is composed of finely crushed, processed bone, usually from cattle but sometimes also from horses. Bone marrow may also be added to the product. Calcium in bone meal occurs as a calcium phosphate compound known as hydroxyapatite or hydroxylapatite. Hydroxyapatite is an inorganic compound found in the matrix of bone and the teeth; it confers rigidity to these structures. The formula of hydroxyapatite is $\left(\mathrm{Ca}_{3}\left(\mathrm{PO}_{4}\right)_{2}\right)_{3}$ $\mathrm{Ca}(\mathrm{OH})_{2}$ or $\mathrm{Ca}_{10}(\mathrm{PO} 4)_{6}(\mathrm{OH})_{2}[\mathrm{l}]$.

Since late 2000 [2] in France and early 2001 [3] in the rest of Europe, lowrisk Meat and bone meal (MBM) is no longer used in animal feeds. Other applications including MBM have been proposed, such as phenolic concrete blocks (without Portland cement), composed of $85 \%$ raw $\mathrm{MBM}$ and $15 \%$ phenolic resin acting as the cementing part [4]. According to its inventors, the material was $30 \%$ cheaper than traditional concrete and oflered adequate modeling, strength and fire resistance properties [5]. At present, all MBM ash goes to landfill, but there is potential for it to be used in various types of concrete such as mass concrete, dry lean bases and sub-bases for road construction and for building blocks. The ash as supplied is fine and there is potential for it to be used at substitution levels of up to $10 \%$ by weight of normal concrete or up to
$20 \%$ of lean concreles road CBM or building blocks [6]. Meat and bone meal bottom ash has the physical aspect of a fine sand, with a grading between 0 and 2 $\mathrm{mm}$ and a mean diameter of 0.4 The bulk density of MBM-BA is around $900 \mathrm{~kg} / \mathrm{m}^{3}$, much lower than that of the sand commonly used in cement-based materials $\left(1500 \mathrm{~kg} / \mathrm{m}^{3}\right)$. The average density of the particles is $2900 \mathrm{~kg} / \mathrm{m}^{3}$. The external specific area, calculated from the density and the particle size distribution (considering cyjindrical particles), is about $3 \mathrm{~m}^{2} / \mathrm{g}$. Optical and electronic microscopy shows that MBM-BA is composed of irregular particles. Many grains present a porous texture; The BET method gives a specilic area of $3000 \mathrm{~m}^{2} / \mathrm{kg}$. which is a thousand times higher than the value calculated using flic parlicle size distribution. This signifieant difference is related to a large open porosity of the grains, leading to water absorption of $11 \%$, a very high value compared to normalized siliceous sand (less than 1\%). [7].

Martin and Ludmann [8] presented the effect of MBM-BA on the consistency and compressive strength of cement-based materials. Increasing proportions of MBM$\mathrm{BA}(17 \%, 33 \%, 50 \%$ and $100 \%)$ were used as replacement of siliceous sand in mortars. The water/cement ratios were fixed at 0.50 and 0.85 (total replacement of sand). The results showed that MBM-BA had the physical and mechanical characteristics of sand. It has low friability but it had high water absorption, which led to the use of a super plasticizer, which leads to a recommended use of less than $30 \% \mathrm{MBM}-\mathrm{BA}$ as sand replacement in mortars. The compressive strenglls of mortar containing $17 \%$ of MBM-BA is similar to that of a reference mortar. Regarding these preliminary results, lead us to believe that low-risk MBM-BA could be used in cement-based materials and present a promising way of reusing this residue. 
Recent references have pointed to opportunities for the development of adhesives and sound or thennal insulation from meat and bone meal. [9-11]. Hertz [12] indicated that silica fume concrete is highly prone to spelling and cracking at elevated temperatures. He prepared a special 170-MPa concrete containing $14-$ $20 \%$ silica fume. Five of the filteen $100 \times 200-\mathrm{rnm}$ cylinders exploded when heated to $650^{\circ} \mathrm{C}$. The test results indicaled that on average, the residual compressive strength of silica fume concrete increased with temperature up $10350^{\circ} \mathrm{C}$ and then decreased sharply. The engineering properties of construction materials at elevated temperature are very important for high rise buildings. Of all construction Inaterials, concrete is one of the mosi resistant to heat and lire. Experience has shown that concrete structures are more likely to remain slanding through a fire than are structures made of other materials. Unlike wood, concrete does not burn and unlike steel [13]. Dale [14] reported that a significant mass loss is observed in the temperature range from $100^{\circ} \mathrm{C}$ to $250^{\circ} \mathrm{C}$ corresponding to loss of water from the $\mathrm{CSH}$ gel and aluminate hydrate products such as eltringite. Second significant mass loss occurs in the temperature range $450^{\circ} \mathrm{C}$ to $550^{\circ} \mathrm{C}$, corresponding to loss of water from the calcium hydroxide $(\mathrm{CH})$. This loss is observed in condensed silica-fume concert, because the $\mathrm{CH}$ formed pozzolanic $\mathrm{CSH}$, which loses its water in the same temperature range as the primary $\mathrm{CSH}$.

Until now there is no any sludy related to the effect of higl temperature on mechanical strenglh of bone powder concrete mortar. In the present investigation bone powder (B.P.) was used as an addition by weight of cement $(0 \%$, $5 \%, 10 \%$ and $15 \%$ ). All mortars samples were exposed to six different temperatures of $100,200,300,400,500$ and $600^{\circ} \mathrm{C}$ for 4 hours soaking time with healing al all average rate of $10^{\circ} \mathrm{C} / \mathrm{min}$. The weight loss and residual compressive and tensile strengths due to exposure to those high temperatures were experimentally investigated in the present work.

\section{EXPERIMENTAL PROGRAMMED}

The cement used in momar mixes was ordinary Portand cement (OPC) according to E.S. 373/199. The properties of the used cement are given in Table 1. The used sand was siliceous sand with 100\% passing ASTM sieve No. 4 with a fineness modulus of 2.49. Bone powder (B.P.) used in this research as shown in photo. I was obtained from crushing of animal bones by using Water wheel powered bone crusher. The chemical composition and plyysical properties of bone powder are given in Tables 2, 3. Bone powders were used in cement mortar mixes as an addition with percentages of 0 , 5, 10 and $15 \%$ by weight of cement content. Cubes $70 \times 70 \times 70 \mathrm{mms}$ were prepared for testing under static compression. Cylinders of $75 \mathrm{mms}$ diameter and 150 mons height were prepared for testing under indirect tension test. The mortar constituent materials were balched separalely by weight. Mixing was performed in a small rolating-drum mixer. First, cement and bone powder were mixed in the dry state until a homogeneous mix was observed before mixing the sand to it, and then water was gradually added while mixing continued for about five minutes. All specimens were cast in steel molds, then demolded after 24 hours and cured in fresl water for 28 days. The specimens were then surface dried and placed in a high temperalure furnace. The drying process is necessary to minimize the risk of explosion of the concrete specimens when they are directly subjected to high temperatures within the furnace.

After drying, the specimens were exposed to temperalures of $100,200,300$, 400,500 and $600^{\circ} \mathrm{C}$ and kepl at that 


\section{81 M.H. Seleem, M. M. Balaha, M. H. A. Kotb and H. Abd el-Rahman}

temperature for 4 hours in the furnace with an average heating rate of $10^{\circ} \mathrm{C}$ per minute. After heating, the specimens were left to cool in air until the time of testing. The compressive and indirect tensile tests were carried out in a hydraulic universal testing machine of $1000 \mathrm{kN}$ capacity. Cracking of specimens after heating were recorded and observed.

\section{RESULTS AND DISCUSSIONS Mass Loss}

The mass losses percentage were estimated as the difference in the mass between the unheated and heated specimens to that of the unheated specimens and then multiplied by 100 . The effect of high-elevaled temperalures on the mass loss percentage of the four mortar mixtures considered $\left(M_{B 0}, M_{195}, M_{B 10}\right.$ and $M_{1015}$ ) are illustrated in Fig. I. In the figure. the mass loss was represented against the target temperatures. Al! mixtures demonstrated an increase in the relative mass loss with increasing temperature. The loss rate is fast at the first stages of heating up to temperature of $200^{\prime \prime} \mathrm{C}$. lihe mix ol bone powder percentage equal to $15 \%$ recorded the highest relative mass loss while that of $0 \%$ bone powder recoded the lowest relative mass loss. The specimens, which contained $15 \%$ B.P., started to crack at $500^{\circ} \mathrm{C}$ and continued to crack severely as the temperature increased. This result clearly indicates that higher water evaporation leads to more weight loss due to heating. The loss rate is high at low temperatures up $10200^{\circ} \mathrm{C}$, after that it stabilized before increasing again above $500^{\circ} \mathrm{C}$. When the heating temperature is under $200^{\circ} \mathrm{C}$, the mass loss is completely caused by quick evaporation of capillary water, and concrete undergoes a physical process. For a temperature between 200 and $400^{\circ} \mathrm{C}$, the weight loss is mainly caused by gradual evaporation of gel water and the concrete undergoes a mix physicochemical process. For a iemperature over $400^{\circ} \mathrm{C}$, the weight loss is mainly caused by evaporation of chemically combined water (dehydration) and decomposition, so the concrete undergoes a chemical process [15].

Figure 2 demonstrates the effect of B.P. percentage on the relative mass losses of mortar specimens at different high temperatures. The figure clearly indicates an increase in the mass loss with increasing bone powder content. These losses are increased with increasing target temperatures. The cement mortar mixtures with different bone powder percentages at temperature of $600^{\circ} \mathrm{C}$ recorded the highest relative mass loss while that at $100^{\circ} \mathrm{C}$ recoded the lowest relative mass loss.

\section{Compressive Strength}

The effect of high temperature on the relative compressive strength of concrete mortar specinens for B.P.,\% equal to $0 \%, 5 \%, 10 \%$ and $15 \%$ are shown in Figs. (3-a, b, c. d, and e.). The relative compressive strenglh here is delited as follows:

Relalive compressive strength $=\left[\sigma_{\mathrm{CH}} /\right.$ $\left.\sigma_{C R T}\right] \times 100$

Where $\sigma_{\mathrm{CH}}$ is the compressive strength of the specimen that exposed to the desired target temperature and $\sigma_{\mathrm{CKT}}$ is the corresponding compressive strength of the unheated specimens at room temperature at the same B.P.,\%. Figures (3-a to e) indicated that the compressive strength for alt B.P.\% decreased compared to that measured at room temperature (without heating). Initially, as the temperature increased to $100^{\circ} \mathrm{C}$, the average relative compressive strength for all B.P.\% decreased compared to heat measured at room temperature (without heating) by a value $8 \%$. With further increase in temperature up to $300^{\circ} \mathrm{C}$, the average relative compressive strength increased compared to that measured at $100^{\circ} \mathrm{C}$ by $3 \%$ and $6 \%$ for target temperatures of respectively $200^{\circ} \mathrm{C}$ and $300^{\circ} \mathrm{C}$. Above 
temperature of $300^{\prime \prime} \mathrm{C}$, the compressive strength markedly decreased compared to heat measured at $100^{\circ} \mathrm{C}$ by a value 9,17 and $54 \%$ for target temperatures equal to 400,500 and $600^{\circ} \mathrm{C}$ respectively. It is clear also that, all mortar mixes exposed to high temperatures suffered a significant depression in compressive strength compared to that measured at room temperature. The significant strength loss after $500^{\circ} \mathrm{C}$ is mainly due to the loss of water from ilue tree calcium hydroxide (CH) (results from cement hydration), leaving calcium oxide (quick lime). This calcium oxide absorbs water from the surrounded atmosphere as the specimen leaved to cool. Thus it is re-hydrated $10 \mathrm{CH}$ or reacts with atmospheric $\mathrm{CO}_{2}$ resulting in the formation of calcium carbonate $\left(\mathrm{CaCO}_{3}\right)$. These processes arc accompanied by an expansion in the volume, which may disrupt the material $[16,17]$. Thermal decomposition of some binding products such as Ca-sulphatealuminate hydrate and calcium silicate hydrates may be also a reason for the higher reduction in the compressive strength at high temperature.

To explain the role of B.P.\% on controlling the behavior of mortar at high temperature, the compressive strongth of the healed mortar specimen wilh different B.P. $\%\left(\sigma_{C}\right)$ was divided to that with B.P.\% equal to $0 \%\left(\sigma_{C O}\right)$, and the results at different temperatures are shown in Fig. 4. The effect of B.P $\%$ at different temperatures shows similar trends, i.e. an increase in the strength ratio as the B.P.\% increases up to B.P. $\%=5 \%$ and after that it decreases at all temperature. Also it is clear that the strength ratio increases as the exposed temperature increases especially at temperatures of 500 and $600^{\circ} \mathrm{C}$ for B.P. $\%$ equal to $5 \%$. As an example for B.P.\% equal to $5 \%$, the sirength ratio reached $121.7 \%$ at $500^{\circ} \mathrm{C}$ and $116.3 \%$ at $600^{\circ} \mathrm{C}$. The decrease in the strength with further increase in B.P added to the cement may be because by increasing (he bone powder without the equivalent required amount of cement to achieve pozzolanic hydration, an adverse effect on the bond in the matrix is occurred.

Photo.2 shows the crack pattern of the concrete mortar specimens after exposed to temperature of $600^{\circ} \mathrm{C}$ for all B.P. $\%$. A wide crack is observed on the specimen surface for B.P. \% equal to $15 \%$ compared to a very narrow surface cracks in the case of B.P.\% equal to $5 \%$. In specimens heated previously at temperatures lower or equal to $400^{\circ} \mathrm{C}$, cracks appear later than in specimens heated at temperatures greater than $400^{\circ} \mathrm{C}$. However, the cracks in the former case grow very fast and a main diagonal crack can be seen clearly.

\section{Teusile Strength}

The effect of high temperature on the relative tensile strength of concrete mortar specimens fabricated with B.P.\% equal to $0 \%, 5 \%, 10 \%$ and $15 \%$ were shown in Figs. (5-a, b, c, d, and e). The relative tensile strength here is defined as follows:

Relative tensile strength $=\left[\sigma_{\mathrm{TI}} / \sigma_{\mathrm{TR} T}\right] \times$ 100

Where $\sigma_{\text {TII }}$ is the tensile strength of the specinen that exposed to the desired target temperature and $\sigma_{\mathrm{IR} I}$ is the corresponding tensile strength of the unheated specimens at room temperature at the same B.P.\%. Initially, as the temperature increased to $100^{\circ} \mathrm{C}$, the average relative tensile strength for all B.P.\% decreased compared to that measured at room temperalure (without heating) by a value $9 \%$. With further increase in temperature up to $300^{\circ} \mathrm{C}$, the average relative tensile strength increased compared to that measured at $100^{\circ} \mathrm{C}$ by a value $2 \%$ and $6 \%$ for target temperatures of respectively 200 and $300^{\circ} \mathrm{C}$. Above temperature of $300^{\circ} \mathrm{C}$, the tensile strength markedly decreased compared to that measured at $100^{\circ} \mathrm{C}$ by a value $2.5,11.7$ and 


\section{83 M.H. Seleem, M. M. Balaha, M. H. A. Kotb and H. Abd el-Rahman}

$48 \%$ for target temperatures equal to 400 , 500 and $600^{\circ} \mathrm{C}$ respectively. It is clear also that, all mortar mixes exposed to fire suffered a significant depression in tensile strength compared to that measured at room temperature. As the temperature rises above $300^{\circ} \mathrm{C}$, small part of the decomposed paste is re-sintered into clinker and recovers little binding capability. In addition, cement paste starts to shrink when heated above $300^{\circ} \mathrm{C}$. Due to different rates of expansion, cracks may occur on the surface of the concrete mortar.

To explain the role of B.P.\% on controlling the behavior of mortar at high temperature, the tensile strength of the heated mortar specimen with different B.P.\% $\left(\sigma_{1}\right)$ was divided to that with B.P.\% equal to $0 \%\left(\sigma_{10}\right)$ at the different regimes of high temperatures including RT as shown in Fig. 6. The same trends shown in the compressive strengths were observed in the case of tensile strengths. For example an increase in the strength ratio is observed when the B.P.\% increases up to B.P.\% $=5 \%$ and after that it decreases at all temperature. Also it is clear that the strength ratio increases as the exposed temperature increases especially at temperatures of 500 and $600^{\circ} \mathrm{C}$ for B.P.\% equal to $5 \%$. As an example for B.P. \% equal to $5 \%$, the strength ratio reached $128.8 \%$ and $127.8 \%$ at temperature equal to $500^{\circ} \mathrm{C}$ and $600^{\circ} \mathrm{C}$ respectively. The high temperature tends to change the mechanism of ettringite formation. Ettringite hydrates begin to dehydrate with this temperature range and ettringite ruptures and disintegrates. The decrease in volume of the hydrate phase and the coarsening of the pore structure of cement mortar are the main reasons influencing mechanical properties decrease at high temperature attack [18].

\section{CONCLUSIONS}

This paper investigated the eflect of high-elevated temperatures on mass loss, the compressive and tensile strength of cement mortar incorporating grounded bone. The results of the work reached to the following conclusions:

1- All mortar mixes exposed to high temperature suffered a significant depression in compressive strength compared to heat measured at room lemperature.

2- As the temperature increased to $100^{\circ} \mathrm{C}$, the compressive and tensile strength for afl B.P.\% decreased compared to that measured at room temperature (without heating). With further increase in temperature up to $300^{\circ} \mathrm{C}$, the compressive and tensile strength increased compared to heat measured at $100^{\circ} \mathrm{C}$. Above temperature of $300^{\circ} \mathrm{C}$, the compressive strength markedly decreased compared to heat measured at $100^{\circ} \mathrm{C}$.

3- An increase in the compressive and tensile strength as the B.P. \% increases up to B.P. $\%=5 \%$ and after that it decreases at all temperature. Also it is clear that the strength ratio increases as the exposed temperature increases especially at temperatures of 500 and $600^{\circ} \mathrm{C}$ for B.P. $\%$ equal $105 \%$.

4. The mass loss increased with increasing of temperature up to $600^{\circ} \mathrm{C}$ and B.P. $\%$.

5- A wide crack is observed on the specimen surface for B.P.\% equal to $15 \%$ compared to a very narrow surface cracks in the case of B.P.\% equal to $5 \%$.

\section{REFERENCES}

1- http:/www.federalabs.com/ bone meal powder.htm, "Bulk Manufacturer of Bone Meal Powder".

2- Arrêté du. "Portant Interdiction de L'emploi de Certaines Protéines d'Origine Animale dans l'alimentation et la Fabrication d'aliments destinés aux Animaux de l'espèce Bovine et 
étendant Celte Interdiction à...d'autres Animaux", Journal Officiel de la République Française, No 264, 15/11/2000, p. 18081.

3- European Council Decision $2000 / 766 /$ EC of 4 December 2000," concerning certain protection measures witl, regard to transmissible spongiform encephalopathies and the feeding of animal protein", Orficial Journal of the European Union, L 306, vol. 43, 07/12/2000 (2000) 32-33.

4- Agence France-Presse - AFP (2001)," Une entreprise propose de fabriquer du "béton" avec des farines animals", communiqué du 5 Février 2001 . http://www.pressed.com.

5- isabelle Duffaure-Gallais (2001)," Non aux farines animales dans le beion!", CSTB Magazine 136, Juillet-Août 2001, p. 46. hitp://www.cstb.fr/cstb_mag/magazine s/2001/136/MAG136_sante.pdf.

6- Dr Rod Collins, "Feasibility of ProducingConcrete Products from Meat and Bone Meal Ash", Client report number209-787, Building Research Establishment Lid 2003.

7- AFNOR, "Methods ol lesting cement: Part 1. Determination of strength", European Standard NF EN 196-1, August 1995.

8- Martin, C., and Ludmann, C., "Low Risk Meat and Bone (MBM) Bollom Ash in Mortar as Sand Replacement ". Laboratoire Materiaux et Durabilite des Constructions INSA - UPS, 135 Avenue de Rangueile, 31077 Toulouse Cedex 04, France. October 2005.
9- Hettiarachichy, NS. 2000. JOPCS 77 (November): 1223-1227.

10- Thomsen, R.,"Patent \#DE 20101411", Germany: 8, July 2002

11- Steenheuer, C.; and Hobohn, F., "Patent HDE10065095", Germany, July 2002

12- K.D. Hertz, Heat-induced explosion of dense concretes, Report No. 166, Institute of Building Design, Technical University of Denmark, Lyngby, 1984.

13- Muszynski LC, Gulas S. "Fire resistance and performance of alternative concrete wall systems", J Constr Educat 2001; 6(3):146-54.

14- Dale P. Bentz. Fiber percolation and spatling of higlt pertormance concrete, ACI Material Journal, P'] 1-24, 2000.

15- Lea, F. M., (1998), The Chemistry of Cement and Concrete, 4th Edn, Arnold Pub. Group, London.

16- Peter, C. Hewlett, (1998), Lea's chemistry of cement and concrete. Copublished in North Central and South America by Jhon Wiely \& Sons Inc., New York and Toronto, 4th edition.

17. Wei-Ming Lin, Lin, T. D. and PowersCouche, (1996), Microstructures of fire-damaged concrele. $\mathrm{ACl}$, Malerial Journal, Vol. 93, No. 1, pp 199-205.

18- Abo-EJ-Enein, 1.A., Hanafi, 1., Hekai, E.E., 1998, "Thermal and physicochemical studies on eltringite:, Part II, Dehydration and thermal stability, If Cemento 2, 121-131. 
C. 85 M.H. Seleem, M. M. Balaha, M. H. A. Kotb and H. Abd el-Ralyman

Table 1 Properties of the used OPC.

\begin{tabular}{|l|c|c|}
\hline \multicolumn{1}{|c|}{ Property } & Results & B.S. Limits \\
\hline Initial setting time & $1.45 \mathrm{hr}$ & $\geq 45 \mathrm{~min}$ \\
\hline Final setting time & $4.25 \mathrm{hr}$ & $\leq 10 \mathrm{hr}$ \\
\hline Fineness, $\mu \mathrm{m}$ & 8 & $\leq 10$ \\
\hline Compressive strength & & \\
$\left(\mathrm{kg} / \mathrm{cm}^{2}\right)$ & & \\
After 3 days & 225 & $\geq 160$ \\
After 7 days & 297 & $\geq 240$ \\
After 28 days & 379 & $\geq 360$ \\
\hline
\end{tabular}

Table 2 Chemical composition of bone powder.

\begin{tabular}{|c|c|c|c|c|c|c|c|c|}
\hline Constituent & $\mathrm{CaO}$ & $\mathrm{SiO}_{2}$ & $\mathrm{Al}_{2} \mathrm{O}_{3}$ & $\mathrm{P}_{2} \mathrm{O}_{5}$ & $\mathrm{Na}_{2} \mathrm{O}$ & $\mathrm{MgO}$ & $\mathrm{K}_{2} \mathrm{O}$ & LOI \\
\hline Content, \% & 52.45 & 1.34 & 0.35 & 36.85 & 1.6 & 1.3 & 0.3 & 1.2 \\
\hline
\end{tabular}

Tabie 3 Physical properties of bone powder.

\begin{tabular}{|c|c|}
\hline Property & Value \\
\hline Specific gravity & 1.85 \\
\hline Unit weight $\mathrm{kg} / \mathrm{m}^{3}$ & 690 \\
\hline Finness, \% & 7 \\
\hline Color & Light-yellow \\
\hline
\end{tabular}

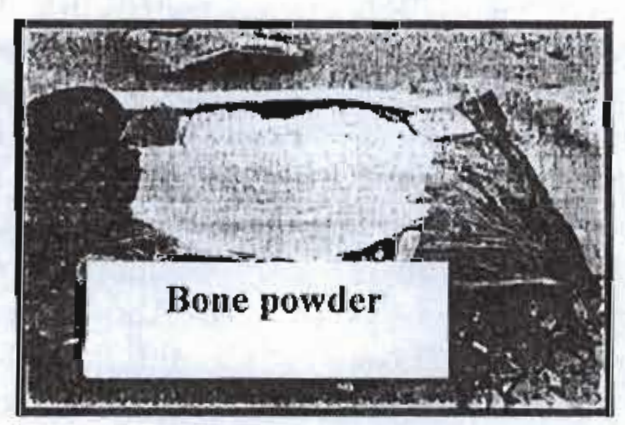

Photo 1: 13one powder

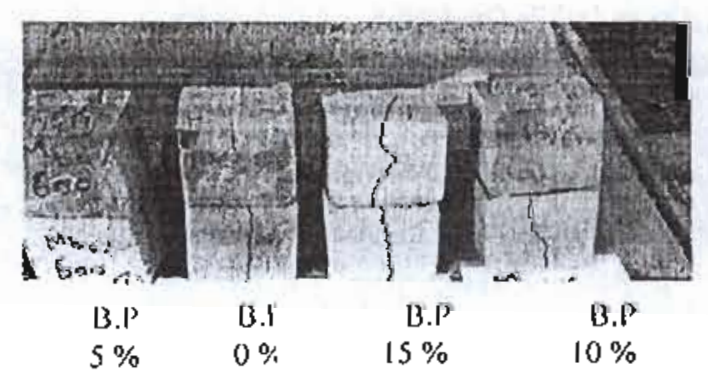

Pholo 2: Crack pattern of mortar specimens after heating to $600^{\circ} \mathrm{C}$. 


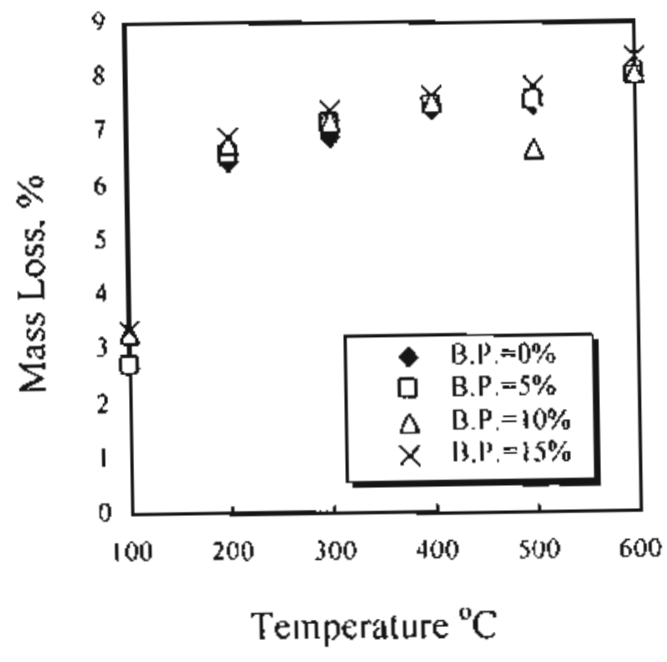

Fig. 1: Mass loss \% vs temperature ${ }^{\circ} \mathrm{C}$ for different bone powder $\%$.

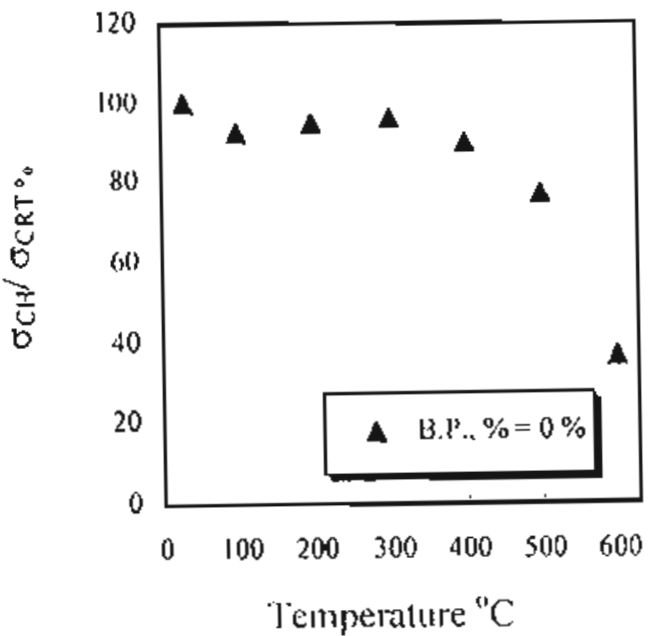

Fig. 3-a: Relative compressive strenglh vs temperalure ${ }^{\circ} \mathrm{C}$ for B. $P^{\prime} \%=0$.

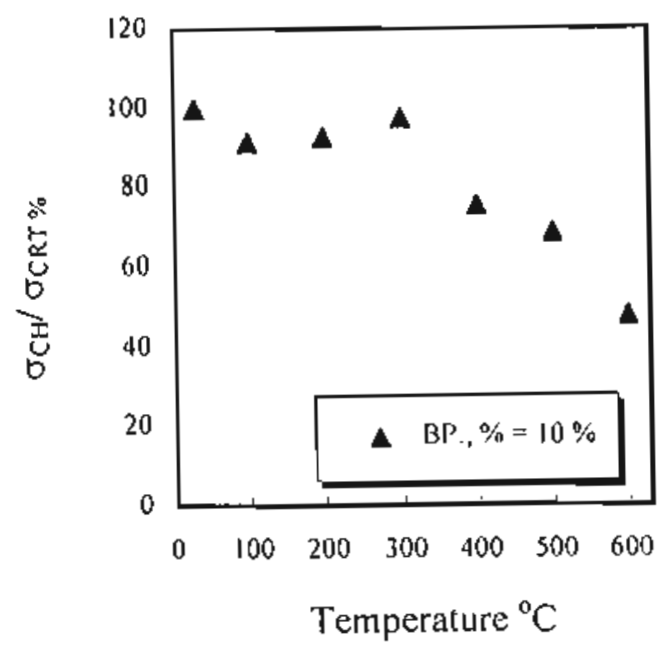

Fig. 3-c: Relative compressive strength vs temperature ${ }^{\circ} \mathrm{C}$ for B.P. $\%=10$.

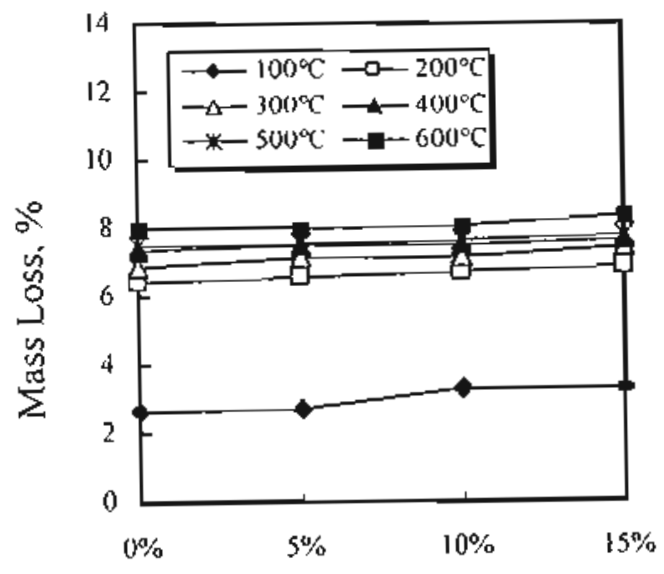

Bone powder \%

Fig. 2: Mass loss \% vs bone powder $\%$ for different temperature ${ }^{\circ} \mathrm{C}$.

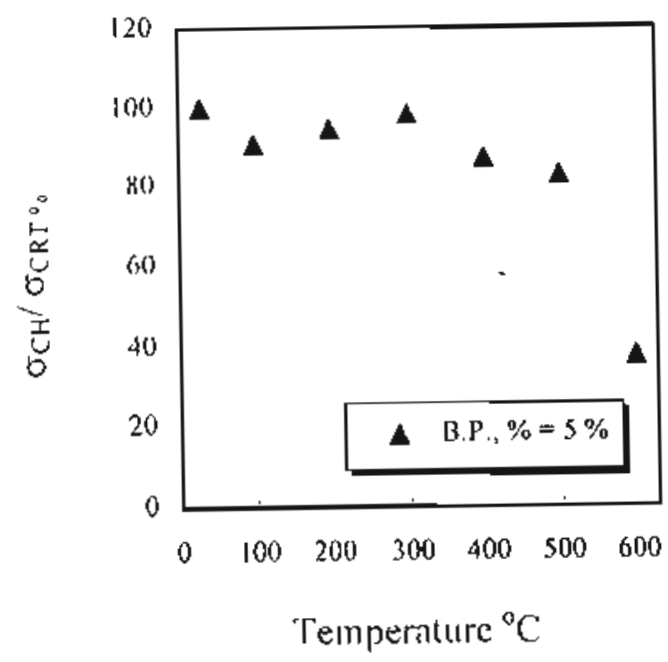

Fig. 3-b: Relative compressive strength vs temperalure ${ }^{\circ} \mathrm{C}$ for $B . P . \%=5$.

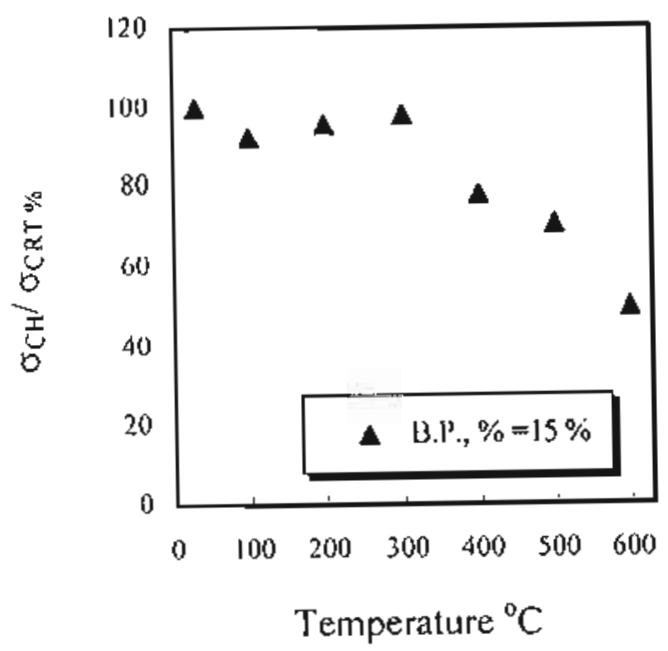

Fig. 3-d: Relative compressive strength vs temperature ${ }^{\circ} \mathrm{C}$ for B.P. $\%=15$. 
C. 87 M.H. Seleem, M. M. Balaha, M. H. A. Koib and H. Abd el-Rahman
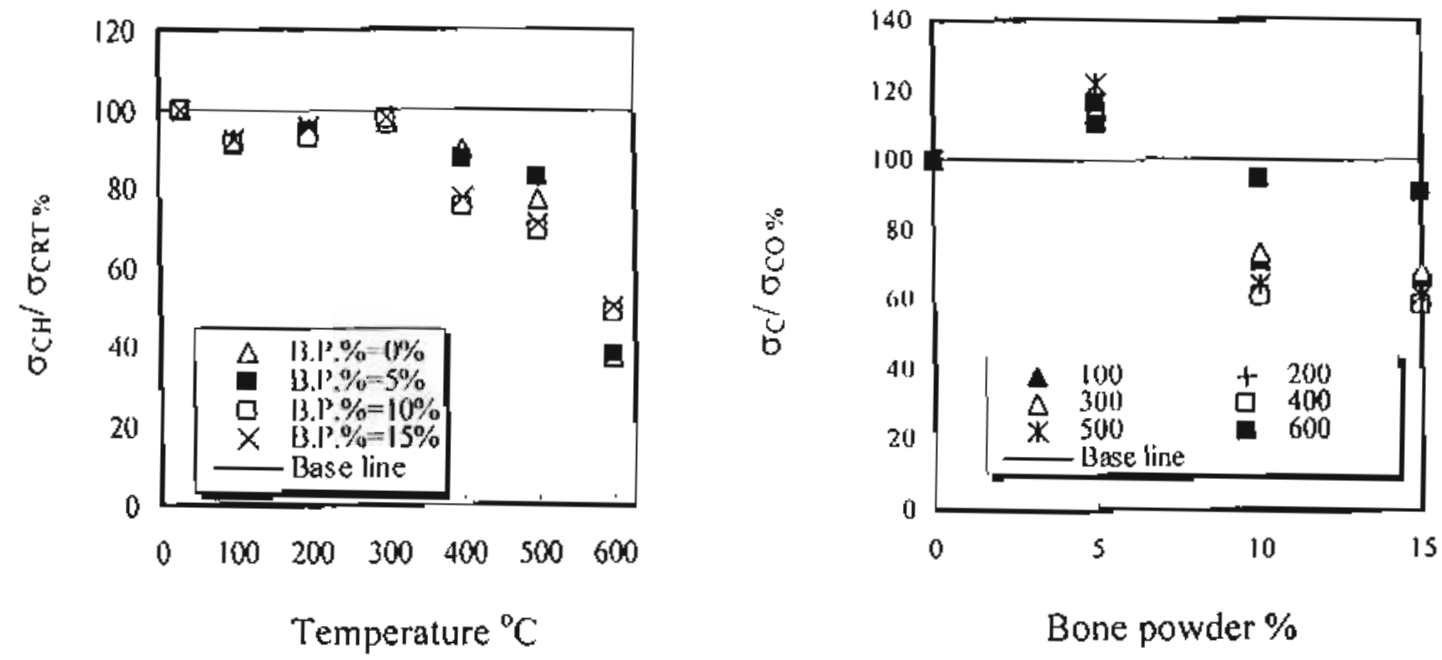

Fig. 3-e: Relative compressive strength vs Fig. 4: Relative compressive strength vs bone temperature ${ }^{\circ} \mathrm{C}$ for different B.P.\%

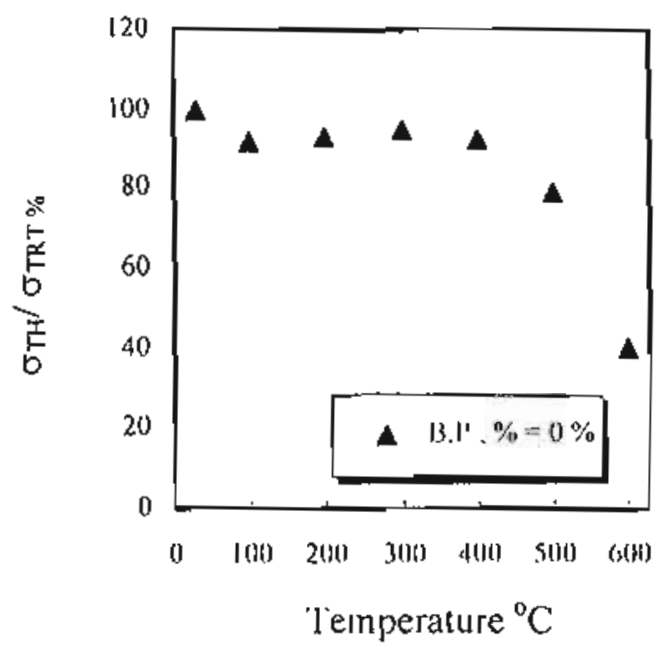

Fig. 5-a: Relative tensile strength vs temperature ${ }^{\circ} \mathrm{C}$ for B.P. $\%=0$.

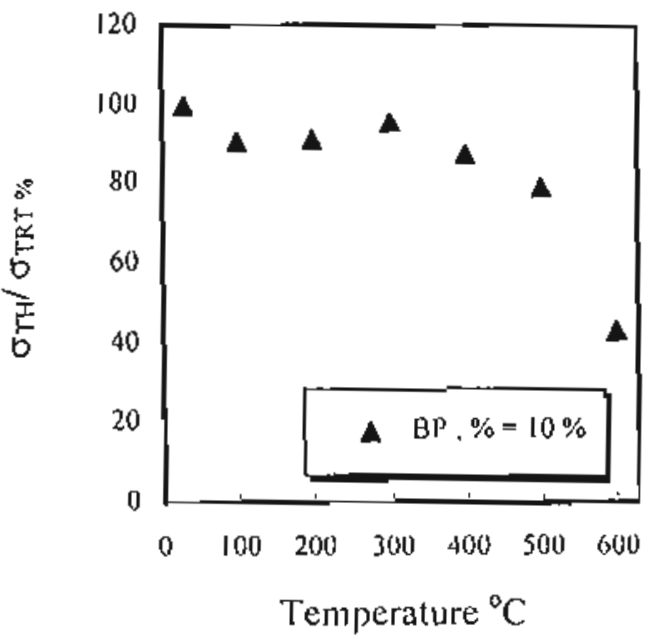

Fig. 5-c: Relative tensile strength vs temperature ${ }^{\circ} \mathrm{C}$ for B.P. $\%=10$

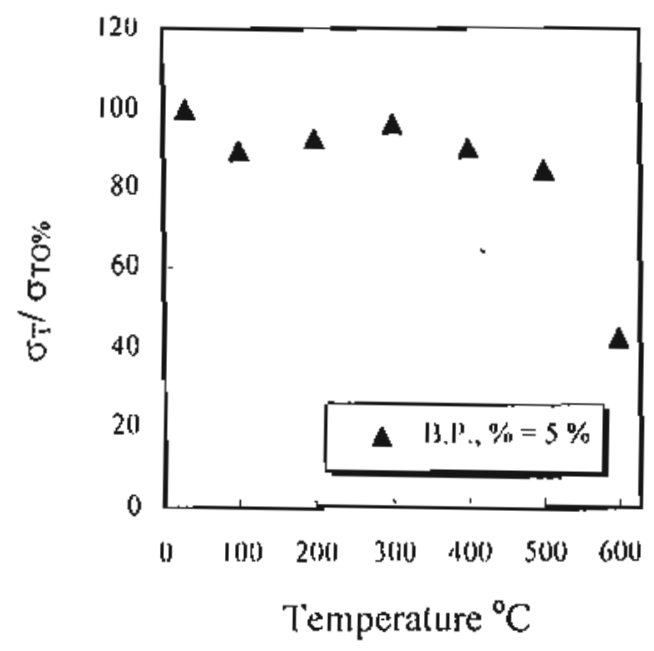

Fig. 5-b: Relative tensile strength vs temperature ${ }^{\circ} \mathrm{C}$ for B.P. $\%=5$.

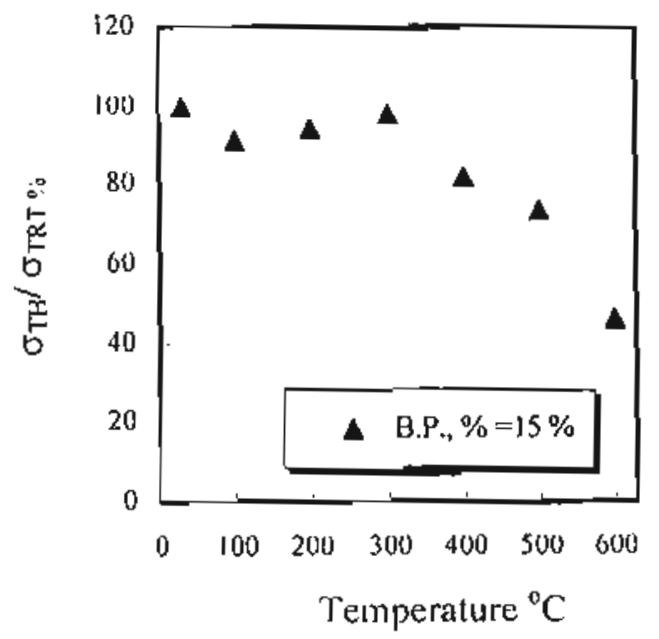

Fig. 5-d; Relative tensile strength vs temperature ${ }^{\circ} \mathrm{C}$ for B.P. $\%=15$. 
Mansoura Enginecring Journal, (MEJ), Vol. 33, No. 2, June 2008.

C. 88

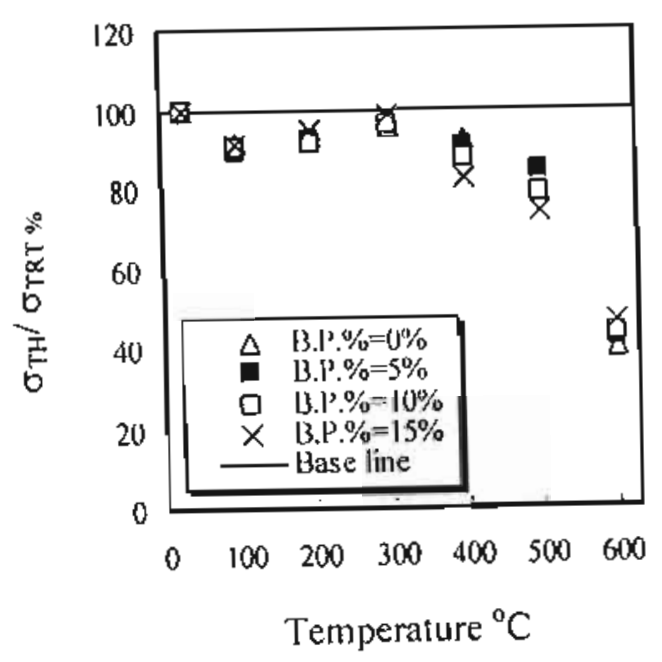

Fig. 5-e: Relative tensile strenglh vs temperature "C for dilterent B.P.\%.

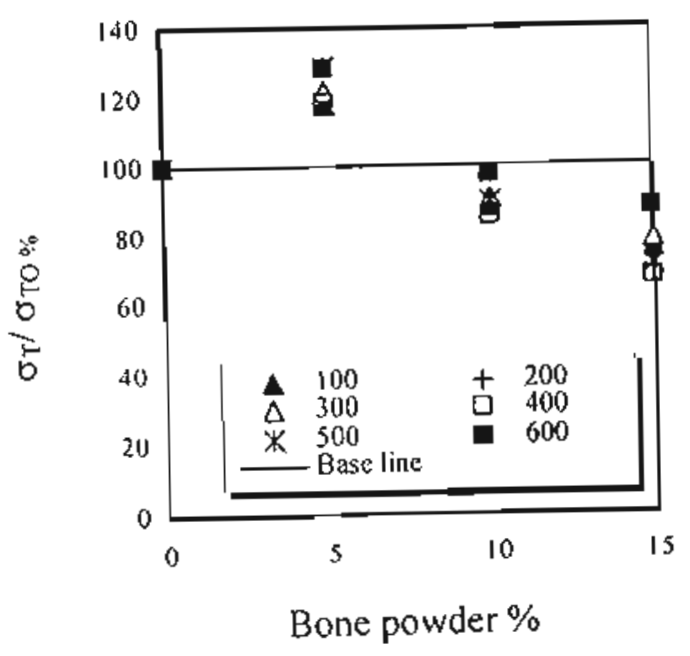

Fig. 6: Relative tensile strength vs bone powder \% lor dilferent 'Temperatures. 